www.nature.com/ja

\title{
Production of monapinones by fermentation of the dinapinone-producing fungus Penicillium pinophilum FKI-3864 in a seawater-containing medium
}

\author{
Kyosuke Kawamoto, Hiroyuki Yamazaki, Satoshi Ohte, Rokuro Masuma, Ryuji Uchida and Hiroshi Tomoda \\ Five new monapinones, including a dinapinone monomer, were isolated from the culture broth of the dinapinone-producing \\ Penicillium pinophilum FKI-3864 in a medium modified to contain seawater. The structures of these monapinones were \\ elucidated by various NMR experiments. Monapinones possessed the same dihydronaphthopyranone skeleton as the \\ dinapinones, with different hydroxyalkyl chains: monapinone $A$ was identified as the monomeric portion of the atropisomer \\ dinapinones $A 1$ and $A 2$, and monapinones $A$ and $B$ showed weak inhibition of triacylglycerol (TG) synthesis in intact mammalian \\ cells, whereas the others showed almost no effect on TG synthesis.
}

The Journal of Antibiotics (2011) 64, 503-508; doi:10.1038/ja.2011.33; published online 25 May 2011

Keywords: dinapinone monomer; monapinone; Penicillium pinophilum; seawater-containing medium; triacylglycerol biosynthesis

\section{INTRODUCTION}

During our screening program to discover inhibitors of triacylglycerol (TG) synthesis using intact Chinese hamster ovary-K1 (CHO-K1) cells, dinapinones A1 (6) and A2 (7) were isolated from the culture broth of Penicillium pinophilum FKI-3864. ${ }^{1}$ These are atropisomers formed from two monomers with the same dihydronaphthopyranone structure. ${ }^{1,2}$ Interestingly, the mixture $(1: 1)$ of 6 and 7 showed full inhibitory activity against TG synthesis in CHO-K1 cells ( $\mathrm{IC}_{50}$, $0.054 \mu \mathrm{M}$ ), although 6 or 7 alone showed less potent activity $\left(\mathrm{IC}_{50}\right.$, 0.65 or $>12 \mu \mathrm{M}$, respectively).

Through our study of the culture conditions for dinapinone production, we found that five new compounds containing the dinapinone monomeric unit-designated monapinones $\mathrm{A}$ (1) to $\mathrm{E}$ (5) (Figure 1) were produced when the dinapinone-producing fungus was cultured in the original medium supplemented with seawater. Interestingly, compounds $\mathbf{1 - 5}$ were produced by the fungus only in the original production medium supplemented with seawater, whereas 6 and 7 were produced very slightly in the same medium. The structure elucidation of $\mathbf{1}$ and $\mathbf{2}$, including their absolute stereochemistry, will be described in detail elsewhere. ${ }^{2}$ In this study, the fermentation, isolation, structure elucidation of 3-5 and TG inhibitory activity of monapinones are described.

\section{RESULTS}

Production of monapinones and dinapinones

Compounds 6 and 7 were originally produced by P. pinophilum FKI3864 , in medium cultured under static conditions. ${ }^{1}$ They were detected as one peak (named dinapinone A, a mixture of 6 and 7) under routine LC/UV analytical conditions using an ODS column. Under the original culture conditions, monapinones were not detected in the culture broth (Figure 2a). An extensive study of the culture conditions for dinapinone production included fermentation in the original production medium supplemented with seawater. This resulted in the appearance of five new peaks with UV spectra similar to that of dinapinone A at earlier retention times on LC/UV analysis (17-26 min vs $27 \mathrm{~min}$ for dinapinone A, Figure $2 \mathrm{~b}$ ). Interestingly, 6 and 7 were hardly detected in this medium (almost constant levels of about $1.5 \mu \mathrm{g} \mathrm{ml}^{-1}$ on day 12 to 30 , Figure $3 \mathrm{a}$ ). The concentrations of 1-5 in the medium were markedly increased on day 15 to 30 after inoculation, and reached almost maximal levels (336.9, 8.5, 97.7, 109.8 and $207.9 \mu \mathrm{g} \mathrm{ml}^{-1}$, respectively, Figure $3 \mathrm{~b}$ ) on day 30 .

Isolation of monapinones A (1) to E (5)

Compounds 1-5 were isolated from the culture broth obtained by the fermentation of $P$. pinophilum FKI-3864 in seawater-supplemented medium. Their isolation procedure is shown in Figure 4. The 30-dayold culture broth $(600 \mathrm{ml})$ was extracted by addition of acetone $(600 \mathrm{ml})$. After the acetone extracts were filtered and concentrated to remove acetone, the aqueous solution was extracted with EtOAc $(600 \mathrm{ml})$. The extracts were dried over $\mathrm{Na}_{2} \mathrm{SO}_{4}$ and concentrated in vacuo to dryness to provide a red-brown material $(1.14 \mathrm{~g})$. The material was dissolved in $40 \% \mathrm{CH}_{3} \mathrm{CN}-\mathrm{H}_{2} \mathrm{O}$, applied to an ODS column $(200 \mathrm{~g})$ and eluted with $\mathrm{CH}_{3} \mathrm{CN}-\mathrm{H}_{2} \mathrm{O}$ stepwise system $(40,50$, 60, 70, 80, 90 and 100\%) containing $0.05 \% \mathrm{H}_{3} \mathrm{PO}_{4}(400 \mathrm{ml}$ for each solvent). The fractions of $90 \% \mathrm{CH}_{3} \mathrm{CN}-\mathrm{H}_{2} \mathrm{O}$ containing $0.05 \% \mathrm{H}_{3} \mathrm{PO}_{4}$ were concentrated in vacuo and extracted with EtOAc to give a 

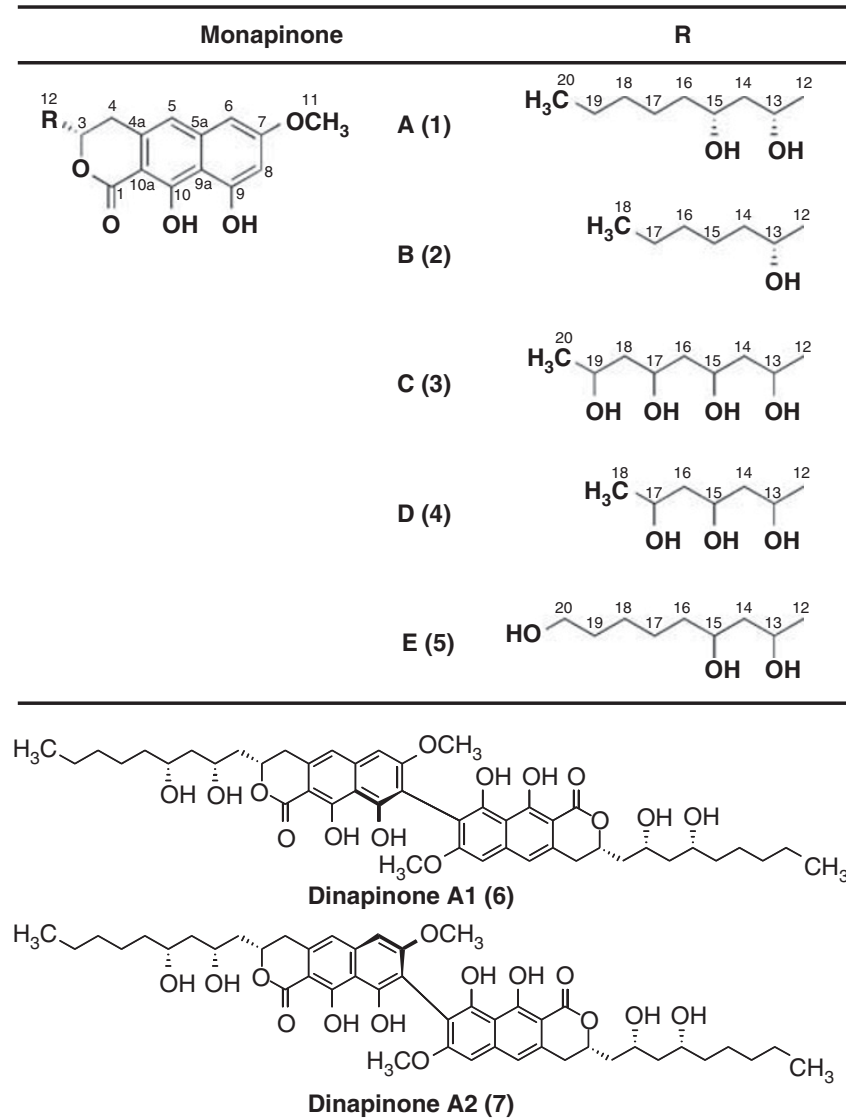

Figure 1 Structures of $1-7$

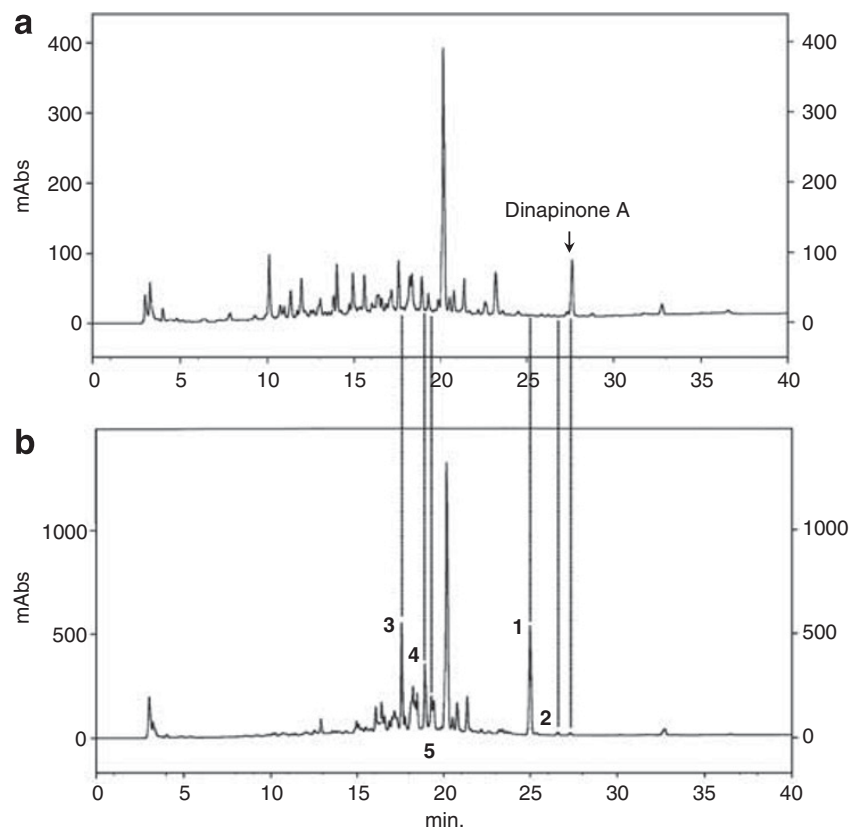

Figure 2 LC/UV analysis of dinapinone-producing Penicillium pinophilun FKI-3864 fermented in the original medium (a) and seawater-supplemented medium (b) under static conditions on day 30 . Dinapinone $A$ is a mixture of 6 and 7 (about 2:3) eluted together by LC/UV using ODS column.
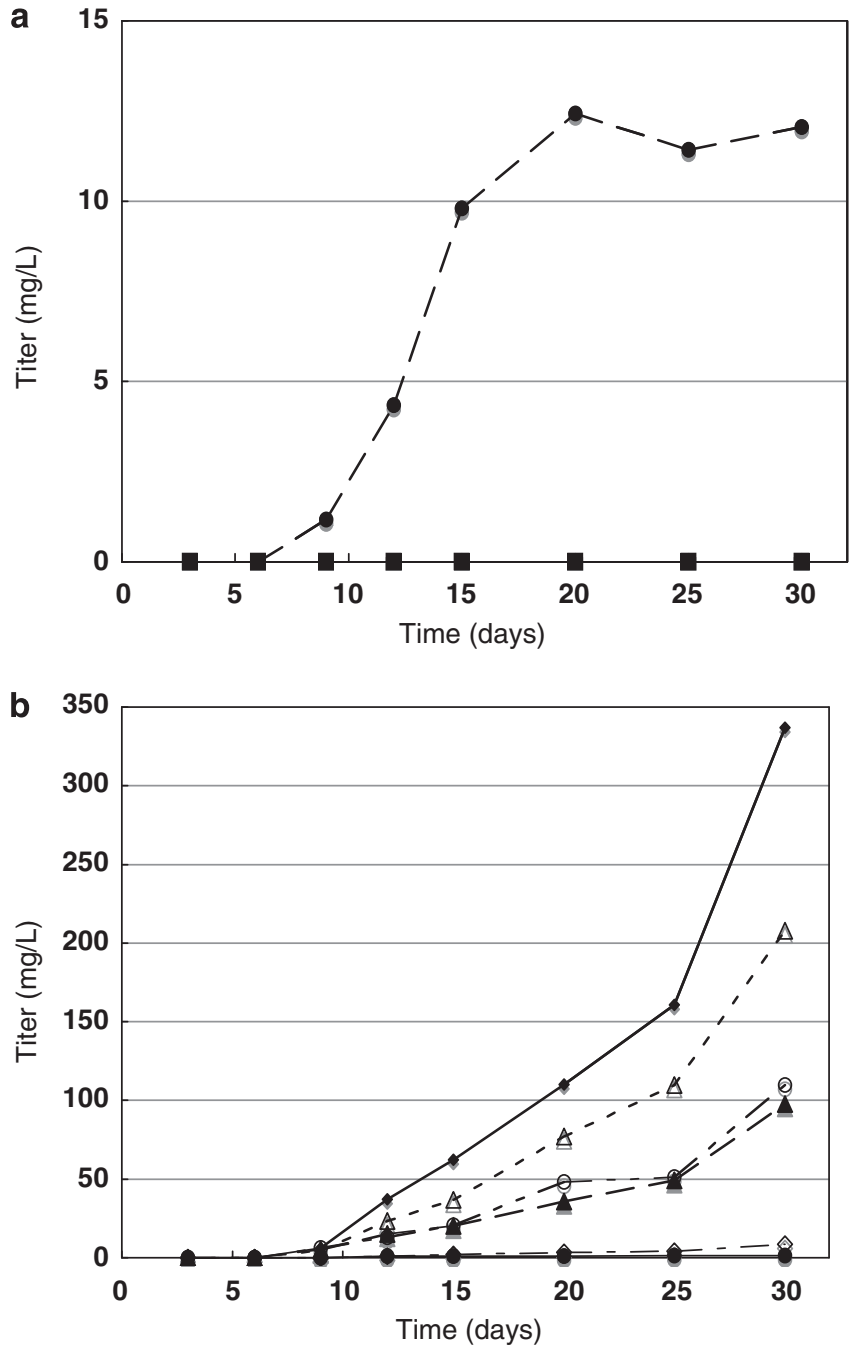

Figure $\mathbf{3}$ Titer of dinapinone A and $\mathbf{1 - 5}$ produced by Penicillium pinophilun FKI-3864 in the original medium (a) and seawater supplemented medium (b) under static conditions for 30 days. - Dinapinone $A,-$ monapinones $A$ to $E, \diamond 1, \diamond 2, \Delta 3, \bigcirc 4$ and $\triangle 5$. Dinapinone $A$ is a mixture of $\mathbf{6}$ and $\mathbf{7}$ (about 2:3) eluted together by LC/UV using ODS column.

red-brown material $(79.8 \mathrm{mg})$. This material was dissolved in $\mathrm{MeOH}$ $(2.0 \mathrm{ml})$ and centrifuged at 3000 r.p.m. to separate $\mathrm{MeOH}$-insoluble and -soluble fractions. The insoluble fraction contained pure $\mathbf{1}$ $(19.0 \mathrm{mg})$, whereas the soluble fraction contained 1 and $2(61.0 \mathrm{mg})$, which were finally purified by preparative HPLC (column, PEGASIL ODS, $20 \times 250 \mathrm{~mm}$, Senshu Scientific, Tokyo, Japan; solvent, 70\% $\mathrm{CH}_{3} \mathrm{CN}-0.05 \% \quad \mathrm{H}_{3} \mathrm{PO}_{4}$; detection, $\mathrm{UV}$ at $210 \mathrm{~nm}$; flow rate, $\left.8.0 \mathrm{ml} \mathrm{min}^{-1}\right)$. Under these conditions, 1 and 2 were eluted as peaks with retention times of 16.2 and $22.2 \mathrm{~min}$, respectively. The fractions were concentrated in vacuo to dryness to give pure $\mathbf{1}(17.9 \mathrm{mg})$ and $\mathbf{2}$ $(0.6 \mathrm{mg})$ as light brown powders. Similarly, the fraction of $70 \%$ $\mathrm{CH}_{3} \mathrm{CN}-0.05 \% \quad \mathrm{H}_{3} \mathrm{PO}_{4}$ was concentrated in vacuo and extracted with EtOAc to give a red-brown material $(213.4 \mathrm{mg})$. The material was finally purified by preparative HPLC (column, PEGASIL ODS, $20 \times 250 \mathrm{~mm}$; solvent, $40 \% \mathrm{CH}_{3} \mathrm{CN}-0.05 \% \mathrm{H}_{3} \mathrm{PO}_{4}$; detection, $\mathrm{UV}$ at $210 \mathrm{~nm}$; flow rate, $8.0 \mathrm{ml} \mathrm{min}^{-1}$ ). Under these conditions, $\mathbf{3}-\mathbf{5}$ were eluted as peaks with retention times of $15.2,19.3$ and $26.2 \mathrm{~min}$, respectively. The fractions were concentrated in vacuo to dryness to 


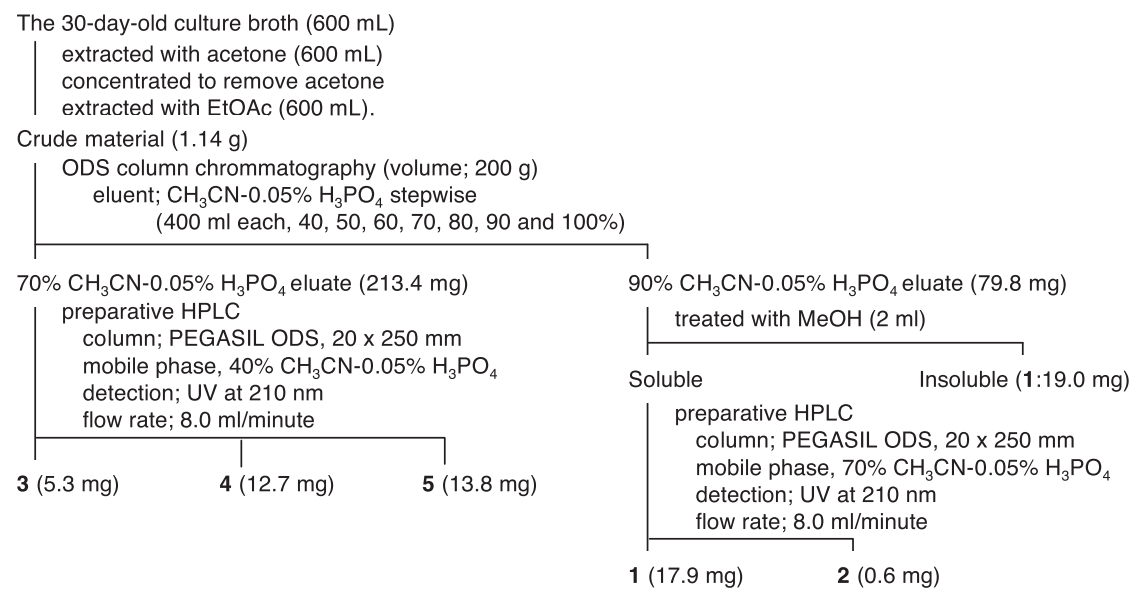

Figure 4 Isolation procedure of $\mathbf{1 - 5}$.

Table 1 Physico-chemical properties 3-5

\begin{tabular}{|c|c|c|c|}
\hline & Monapinone C (3) & Monapinone D (4) & Monapinone E (5) \\
\hline Appearance & Light brown powder & Light brown powder & Light brown powder \\
\hline Molecular weight & 450 & 406 & 434 \\
\hline Molecular formula & $\mathrm{C}_{23} \mathrm{H}_{30} \mathrm{O}_{9}$ & $\mathrm{C}_{21} \mathrm{H}_{26} \mathrm{O}_{8}$ & $\mathrm{C}_{23} \mathrm{H}_{30} \mathrm{O}_{8}$ \\
\hline \multicolumn{4}{|l|}{ HRESI-TOF-MS (m/z) } \\
\hline Calcd. & $449.1812(\mathrm{M}-\mathrm{H})^{-}$ & $405.1549(\mathrm{M}-\mathrm{H})^{-}$ & $433.1862(\mathrm{M}-\mathrm{H})^{-}$ \\
\hline Found & $449.1815(\mathrm{M}-\mathrm{H})^{-}$ & $405.1554(\mathrm{M}-\mathrm{H})^{-}$ & $433.1867(\mathrm{M}-\mathrm{H})^{-}$ \\
\hline $\mathrm{UV}(\mathrm{MeOH}) \lambda_{\max } \mathrm{nm}(\varepsilon)$ & 219 (34 000), 261 (88500), 370 (19500) & 220 (41 100), 261 (119200), 369 (26 000) & 219 (30600), 261 (77800), 371 (15 100) \\
\hline$[\alpha]_{D}^{26}$ & $-11.6^{\circ}\left(c=0.10, \mathrm{CH}_{3} \mathrm{OH}\right)$ & $-15.3^{\circ}\left(c=0.10, \mathrm{CH}_{3} \mathrm{OH}\right)$ & $+6.56^{\circ}\left(c=0.10, \mathrm{CH}_{3} \mathrm{OH}\right)$ \\
\hline $\mathrm{IR}(\mathrm{KBr}) v_{\max }\left(\mathrm{cm}^{-1}\right)$ & $3435,2929,1639$ & $3425,2929,1645$ & $3431,2931,1637$ \\
\hline
\end{tabular}

give pure $3(5.3 \mathrm{mg}), \mathbf{4}(12.7 \mathrm{mg})$ and $\mathbf{5}(13.8 \mathrm{mg})$ as light brown powders.

Structure elucidation of monapinones C (3) to E (5)

The structure elucidation including the absolute stereochemistry of $\mathbf{1}$ and 2 were reported and described elsewhere. ${ }^{2}$ The physico-chemical properties and of 3-5 are summarized in Table 1. The compounds had similar UV-visible spectra with absorption maxima at 219-220, 261 and $369-371 \mathrm{~nm}$. The IR absorption at 1637-1645, 2929-2931 and $3425-3435 \mathrm{~cm}^{-1}$ suggested the presence of carbonyl groups, an alkyl chain and hydroxyl groups in their structures. These data were similar to those of 1 and $2,{ }^{2}$ indicating that they share the same skeleton.

Monapinone C (3). The molecular formula of 3 is $\mathrm{C}_{23} \mathrm{H}_{30} \mathrm{O}_{9}$, on the basis of HRESI-MS, indicating that 3 contains two more oxygen atoms than 1. Comparison of the ${ }^{1} \mathrm{H}$ and ${ }^{13} \mathrm{C}$ NMR spectra (Table 2) between 1 and 3 indicated that the methylene protons of $\mathrm{H}_{2}-17(\delta 1.31)$ and $\mathrm{H}_{2}-19(\delta 1.31)$ in 1 are replaced by the oxygenated methine protons of $\mathrm{H}-17(\delta 3.96)$ and $\mathrm{H}-19(\delta 3.96)$ in 3. Accordingly, compound 3 was identified as 17, 19-dihydroxy 1 (Figure 1), which satisfied the degree of unsaturation and the molecular formula.

Monapinone $D$ (4). The molecular formula of 4 is $\mathrm{C}_{21} \mathrm{H}_{26} \mathrm{O}_{8}$, indicating that 4 contains two more oxygen atoms than 2. Comparison of the ${ }^{1} \mathrm{H}$ and ${ }^{13} \mathrm{C}$ NMR spectra (Table 2) between 2 and 4 indicated that the methylenes at positions 15 and 17 in 2 are replaced by oxygenated methines in 4 . Accordingly, compound $\mathbf{4}$ was determined to be 15, 17-dihydroxy 2 (Figure 1), which satisfied the degree of unsaturation and the molecular formula.

Monapinone $E$ (5). The molecular formula of $\mathbf{5}$ is $\mathrm{C}_{23} \mathrm{H}_{30} \mathrm{O}_{8}$, indicating that 5 contains one more oxygen atom than $\mathbf{1}$. Comparison of the ${ }^{1} \mathrm{H}$ and ${ }^{13} \mathrm{C}$ NMR spectra (Table 2) between $\mathbf{1}$ and $\mathbf{5}$ indicated that the methyl protons $\left(\mathrm{H}_{3}-20, \delta 0.90\right)$ in 1 are replaced by the oxygenated methylene protons $\left(\mathrm{H}_{2}-20, \delta 3.35\right)$ in 5. Accordingly, compound 5 was determined to be 20-hydroxy 1 (Figure 1), which satisfied the degree of unsaturation and the molecular formula.

As described elsewhere, ${ }^{2}$ the absolute stereochemistry of 1 and 2 was determined as $3 S 13 R 15 R$ and $3 S 13 R$, respectively, by coupling constants in ${ }^{1} \mathrm{H}$ NMR, ROESY experiments and CD spectra. To elucidate the absolute stereochemistry of C-3 of 3-5, the CD data of 3-5 were compared with those reported for $(S)$ - and $(R)$ - semivioxanthins. ${ }^{3}$ Accordingly, the absolute stereochemistry at C-3 in 3-5 was elucidated to be $3 S$; however, the stereochemistry at C-13, C-15, C-17 and C-19 of 3-5 was not determined, because the coupling constants in ${ }^{1} \mathrm{H}$ NMR were extremely complicated.

\section{Biological activity}

Effects of monapinones on cholesteryl ester and TG synthesis in animal cells. The effects of all monapinones on cholesteryl ester (CE) and TG synthesis were evaluated in two cell-based assays. The synthesis of $\left[{ }^{14} \mathrm{C}\right] \mathrm{TG}$ and $\left[{ }^{14} \mathrm{C}\right] \mathrm{CE}$ from $\left[{ }^{14} \mathrm{C}\right]$ oleic acid was measured in $\mathrm{CHO}-\mathrm{K} 1$ cells, ${ }^{1}$ and the synthesis of $\left[{ }^{14} \mathrm{C}\right] \mathrm{TG}$ in Raji cells. ${ }^{4}$ The results are summarized in Table 3. Compound 1 inhibited both $\left[{ }^{14} \mathrm{C}\right] \mathrm{TG}$ and 


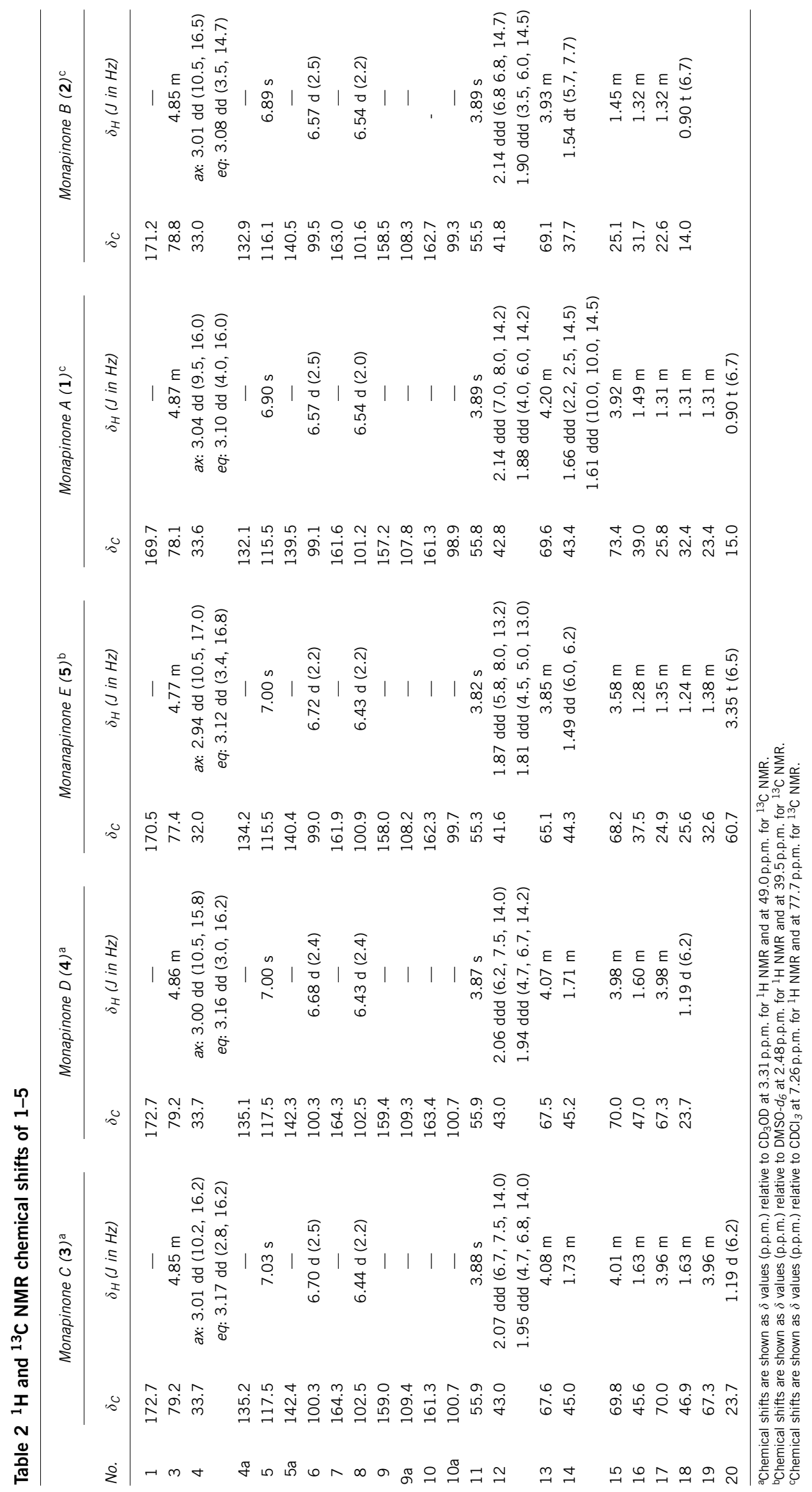


Table 3 Effects of CE and TG synthesis of monapinones and dinapinones in CHO-K1 and Raji cells

\begin{tabular}{lccc}
\hline & \multicolumn{3}{c}{$\mathrm{IC}_{50}(\mu \mathrm{m})$} \\
\cline { 2 - 4 } & \multicolumn{2}{c}{ CHO-K1 cells } & Raji cells \\
\cline { 2 - 4 } & $\mathrm{CE}$ & $\mathrm{TG}$ & $\mathrm{TG}$ \\
\cline { 2 - 4 } & & & \\
\hline Monapinone & 46.6 & 77.1 & 74.0 \\
A (1) & 40.0 & 78.9 & 72.7 \\
B (2) & 100 & $>100$ & $>100$ \\
C (3) & $>100$ & $>100$ & $>100$ \\
D (4) & 38.3 & $>100$ & $>100$ \\
E (5) & &
\end{tabular}

Dinapinone

\begin{tabular}{lccc} 
A & 0.31 & 0.097 & 0.38 \\
A1 (6) & $>12$ & $>12$ & $>12$ \\
A2 (7) & 5.24 & 0.65 & 5.42 \\
\hline
\end{tabular}

Abbreviations: CHO-K1, Chinese hamster ovary-K1; TG, triacylglycerol.

$\left[{ }^{14} \mathrm{C}\right] \mathrm{CE}$ synthesis in $\mathrm{CHO}-\mathrm{K} 1$ cells with $\mathrm{IC}_{50}$ values of 77.1 and $46.6 \mu \mathrm{M}$, respectively. Similarly, 2 inhibited TG and CE synthesis with $\mathrm{IC}_{50}$ values of 78.9 and $40.0 \mu \mathrm{M}$, respectively, whereas 5 selectively inhibited $\mathrm{CE}$ synthesis in a dose-dependent manner with an $\mathrm{IC}_{50}$ value of $38.3 \mu \mathrm{M}$. Compounds 3 and 4 showed no effect on $\left[{ }^{14} \mathrm{C}\right] \mathrm{CE}$ and $\left[{ }^{14} \mathrm{C}\right] \mathrm{TG}$ syntheses up to $100 \mu \mathrm{M}$.

In the Raji cell assay, $\mathbf{1}$ and $\mathbf{2}$ showed weak inhibition of TG synthesis $\left(\mathrm{IC}_{50}, 74.0\right.$ and $72.7 \mu \mathrm{M}$ ), but $\mathbf{3 - 5}$ showed no inhibitory activity up to $100 \mu \mathrm{M}$ (Table 3 ). These findings indicated that inhibition of synthesis by $\mathbf{1}$ and $\mathbf{2}$ was rather weak in both cell-based assays.

\section{DISCUSSION}

From the study of the culture conditions of the dinapinone-producing P. pinophilum FKI-3864, we found that dinapinone A (consisting of atropisomers 6 and 7) was selectively produced in the original (seawater-lacking) medium, whereas monapinones were selectively produced in seawater-supplemented medium. We presumed that a potential converting enzyme from monapinones to dinapinones worked well or was expressed only in the original (seawater-lacking) medium. In this study, various monapinones, including the dinapinone-comprising monomers (1), were isolated from the culture broth, indicating that different members of the dinapinone family can be produced. In fact, dinapinones composed of these monomers were isolated from the culture broth and characterized, which will be reported in the future. We are also performing further biochemical investigations to clarify the mechanism of production from monapinones to dinapinones.

Compounds 6 and 7 were reported to inhibit TG synthesis in a CHO-K1 cell assay. ${ }^{1,2}$ Compound 7 showed selective inhibition of TG synthesis $\left(\mathrm{IC}_{50}, 0.65 \mu \mathrm{M}\right)$, when compared with the inhibition of $\mathrm{CE}$ synthesis $\left(\mathrm{IC}_{50}, 5.24 \mu \mathrm{M}\right)$. Interestingly, although 7 was a very weak and non-selective TG inhibitor, dinapinone $\mathrm{A}$, a mixture of $\mathbf{6}$ and $\mathbf{7}$ in a 2:3 ratio, enhanced TG inhibition $\left(\mathrm{IC}_{50}, 0.097 \mu \mathrm{M}\right)$. Unfortunately, 1 (the common monomer of $\mathbf{6}$ and 7 ) and $\mathbf{2}$ showed weak and non-selective TG inhibition $\left(\mathrm{IC}_{50}, 78.9 \mu \mathrm{M}\right)$. The dimeric nature of the structure might be responsible for selective and potent inhibitory activity of TG synthesis in CHO-K1 cells. As one of the potential targets in the inhibition of TG synthesis, we have studied diacylglycerol acyltransferase (DGAT) and established enzyme assays for the two isozymes, DGAT1 and DGAT2. ${ }^{5}$ Dinapinones and monapinones had no effect on the two isozymes, even at $100 \mu \mathrm{m}$. The target molecule of dinapinones and monapinones remains to be identified.

\section{MATERIALS AND METHODS}

\section{General experimental procedures}

SSC-ODS-7515-12 (Senshu Scientific) was used for ODS column chromatography. HPLC was carried out using the L-6200 system (Hitachi, Tokyo, Japan). UV spectra were recorded on a spectrophotometer (8453 UV-visible spectrophotometer; Agilent Technologies, Santa Clara, CA, USA). IR spectra were recorded on a Fourier transform infrared spectrometer (FT-710; Horiba, Kyoto, Japan). Optical rotations were measured with a digital polarimeter (DIP-1000; JASCO, Tokyo, Japan). CD spectra were measured with a spectrometer (J-720; JASCO). ESI-TOF-MS and HRESI-TOF-MS spectra were recorded on a MS (JMS-T100LP; JEOL, Tokyo, Japan). Various NMR spectra were measured with an NNR spectrometer (XL-400; Varian, Palo Alto, CA, USA).

\section{Microorganisms}

Fungal strain FKI-3864 was isolated from a soil sample collected in Hilo, Hawaii, USA. ${ }^{1}$ This strain was used to produce monapinones.

\section{Fermentation}

A slant culture of strain FKI-3864 grown on LCA $(0.10 \%$ glycerol, $0.08 \%$ $\mathrm{KH}_{2} \mathrm{PO}_{4}, 0.02 \% \mathrm{~K}_{2} \mathrm{HPO}_{4}, 0.02 \% \mathrm{MgSO}_{4} 7 \mathrm{H}_{2} \mathrm{O}, 0.02 \% \mathrm{KCl}, 0.2 \% \mathrm{NaNO}_{3}$, $0.02 \%$ yeast extract and $1.5 \%$ agar, adjusted to $\mathrm{pH} 6.0$ before sterilization) was inoculated into a $50-\mathrm{ml}$ tube containing $10 \mathrm{ml}$ of the seed medium $(2.0 \%$ glucose, $0.5 \%$ polypeptone, $0.05 \% \mathrm{MgSO}_{4} 7 \mathrm{H}_{2} \mathrm{O}, 0.2 \%$ yeast extract, $0.1 \%$ $\mathrm{KH}_{2} \mathrm{PO}_{4}$ and $0.10 \%$ agar, adjusted to $\mathrm{pH} 6.0$ before sterilization). The tube was shaken reciprocally for 3 days at $27^{\circ} \mathrm{C}$ to obtain the seed culture, which was transferred to production medium (3.0\% sucrose, 3.0\% soluble starch, $1.0 \%$ malt extract, $0.3 \%$ Ebios (Asahi Food \& Helthcare, Tokyo, Japan) $0.5 \%$ $\mathrm{KH}_{2} \mathrm{PO}_{4}, 0.05 \% \mathrm{MgSO}_{4} 7 \mathrm{H}_{2} \mathrm{O}$, adjusted to $\mathrm{pH} 6.0$ before sterilization) and fermentation was carried out under the following culture conditions: (1) This was reported as a dinapinone A-producing condition; ${ }^{1}$ (2) The main culture was initiated by transferring $2.0 \mathrm{ml}$ of the seed culture into a 1000-ml Rouxtype flask containing $200 \mathrm{ml}$ of the production medium supplemented with seawater. Fermentation was carried out at $27^{\circ} \mathrm{C}$ for 30 days under stable conditions.

The production of dinapinone A (consisting of atropisomers 6 and 7) and monapinones was measured using a LaChrom Elite HTA system (Hitachi; column, PEGASIL ODS $(4.6 \times 250 \mathrm{~mm}$; Senshu Scientific); flow rate, $1.0 \mathrm{ml} \mathrm{min}^{-1}$; mobile phase, a 40 -min linear gradient from $5.0 \% \mathrm{CH}_{3} \mathrm{CN}$ to $100 \% \mathrm{CH}_{3} \mathrm{CN}$ containing $0.050 \% \mathrm{H}_{3} \mathrm{PO}_{4}$; detection, $\mathrm{UV}$ at $\left.210 \mathrm{~nm}\right)$. Under these conditions, $\mathbf{1 - 7}$ were eluted with retention times of $24.8,26.4,17.6,18.3$ and 19.2 and $27.4 \mathrm{~min}$, respectively, (both 6 and 7 elute at the $27.4 \mathrm{~min}$ peak under these chromatographic conditions).

\section{Biological assays}

Assays for TG, CE and phospholipid synthesis using CHO-K1 cells ${ }^{1}$ and TG and PL synthesis using Raji cells ${ }^{4}$ were carried out by the established methods with some modifications. DGAT activity in microsomes prepared from mouse liver, CHO-K1 cells and DGAT1- and DGAT2-expressing Saccharomyces cerevisiae was assayed according to the method described previously. ${ }^{1,6-8}$

\section{ACKNOWLEDGEMENTS}

We express our thanks to Ms N Sato for performing NMR experiments, and Dr K Nagai and Ms A Nakagawa for measuring mass spectra.

1 Ohte, S. et al. Dinapinones, novel inhibitors of triacylglycerol synthesis in mammalian cells, produced by Penicillium pinophilum FKI-3864. J. Antibiot (e-pub ahead of print 11 May 2011; doi:10.1038/ja.2011.32) (2011)

2 Uchida, R., Ohte, S., Kawamoto, K. \& Tomoda, H. Structures and absolute stereochemistry of dinapinones $A 1$ and $A 2$, novel inhibitors of triacylglycerol synthesis, produced by Penicillium pinophilum FKI-3864 (Unpublished). 
3 Bode, S. E., Drochner, D. \& Müller, M. Synthesis, biosynthesis, and absolute configuration of vioxanthin. Angew. Chem. Int. Ed. Engl. 46, 5916-5920 (2007).

4 Tomoda, H., Igarashi, K., Cyong, J. C. \& Ōmura, S. Evidence for an essential role of long chain acyl-CoA synthetase in animal cell proliferation. Inhibition of long chain acyl-CoA synthetase by triacsins caused inhibition of Raji cell proliferation. J. Biol. Chem. 266, 4214-4219 (1991).

5 Inokoshi, J., Kawamoto, K., Takagi, Y., Matsuhama, M., Ōmura, S. \& Tomoda, H. Expression of two acyl-CoA:diacylglycerol acyltransferase isozymes in yeast and selectivity of microbial inhibitors toward the isozymes. J. Antibiot. 62, 51-54 (2009).
6 Tomoda, H., Ito, M., Tabata, N., Masuma, R., Yamaguchi, Y. \& Ōmura, S. Amidepsines, inhibitor of diacylglycerol acyltransferase produced by Humicola sp. FO-2942. I. Production, isolation, and biological properties. J. Antibiot. 48, 937-941 (1995).

7 Ōmura, S., Tomoda, H., Tabata, N., Ohyama, Y., Abe, T. \& Namikoshi, M. Roselipins, novel fungal metabolites having a highly methylated fatty acid modified with a mannose and an arabinitol. J. Antibiot. 52, 586-589 (1999).

8 Tabata, N., Ito, M., Tomoda, H. \& Ōmura, S. Xanthohumols, diacylglycerol acyltransferase inhibitors, from Humulus lupulus. Phytochemistry 46, 683-687 (1997). 